By this time the Institute membership had grown to more than eight hundred, and in terms of the charter "included a large proportion of the leading Mining Engineers in the United Kingdom". Indeed, a review of the list of members reveals that membership was beginning to be world-wide, and the Institute was becoming a clearing-house of technical information on coal mining in many countries.

'The example set by the North of England was followed by the formation of mining institutes in other coalfields, and the North of England Institute played a leading part in the establishment in London in $\mathbf{1 8 8 9}$ of the Institution of Mining Engineers-now a federation of eight mining institutes from all parts of Britain.

Many historic papers have been read at the meetings of the North of England Institute. In the early years, when many disastrous explosions occurred, particular attention was paid to the ventilation of mines. John Buddle, the "father of English mining', realizing the possible danger of using a furnace to assist in the natural ventilation, invented an air pump-the forerunner of the modern fan. A series of papers by J. J. Atkinson on the principles of mine ventilation laid the foundation of modern ventilation technology. Though Humphry Davy had improved the then safety lamp, his 'Davy lamp' was proved to be unsafe in certain circumstances and improvements were gradually brought about.

Many valuable papers on methods of working and the control of the strata are to be found in the Transactions of the Institute. With regard to methods of working coal seams, as the very shallow seams became exhausted it became necessary to sink deeper shafts and to work a greater area from each shaft, and the first method of really underground working was evolved, namely, the room and pillar method of mining. G. C. (Treenwell in 1852 wrote "A Practical Treatise on Mining Engineering" at a time when there was practically no literature on mining in the English language. The first edition was based on a series of lectures delivered at the Newcastle College of Practical Science-the forerunner of the King's College of to-day. In passing, reference may be made to a statement made by a prominent mining engineer in the United States of America to the effect that their modern method of working is based more or less on Greenwell's ideas.

The Institute had from time to time set up committees to study specific mining problems, and in 1924 "The Support of Workings in Mines Committee" was appointed to investigate the causes of falls and accidents due to falls. In 1930 the Committee was provided with funds by the Safety in Mines Research Board for the appointment of a full-time investigator. The reports of this Committee provide a comprehensive statement of the fundamental factors determining the behaviour of the strata in mining operations.

In 1948 the Northern Divisional Strata Control Research Committee of the National Coal Board was set up. The Committee has a membership representative of the Durham and Northern Divisions of the Coal Board and of the North of England Institute of Mining and Mechanical Engineers, including members of the staff of the Mining Department of King's College, University of Durham. In this way the Institute has been enabled to continue its contributions to its historic work in this field. This is an ideal combination of observation and experiment in mines, together with academic work in the Univer- sity such as photo-elastic research on plastic models of mine workings.

The early pioneers would have been astounded if they could have listened to the most recent paper read at a meeting of the Institute, when successful experiments were described in the getting of coal from very thin seams without any men on the working face at all. Such is the progress made in the mechanization of mining operations.

With such grand traditions, it will not be surprising that the North of England Institute of Mining and Mechanical Engineers is still very actively engaged in research to secure the increased safety and health and well-being of those employed in the mining industry. In addition to the research mentioned on roof control and prevention of falls of ground, there are committees on the lighting and ventilation of mines.

The research on lighting is being carried out with the view, ultimately, of being able to predict the performance of any lighting fitting under any set of mining conditions. The series of tests being done at the moment are designed to investigate the effect of shape of a mine roadway and the reflexion factor of its walls and roof on the utilization factors. This work is being done in the Mining Laboratories at King's College, Newcastle upon Tyne, and tests are also being carried out underground so as to obtain a continual correlation of results. A special photometer has been designed and constructed with which the spherical distribution of any source can be found. Investigations also cover the safety of fluorescent lamp units for use in gassy mines, and a safe signalling system on longwall faces.

The immediate object of the research on ventilation is the formulation of rules and formulæ as the basis for the design of fan drifts.

The first meetings of the Institute were in the lecture room of the Literary and Philosophical Society at Newcastle upon Tyne; but through the enthusiastic efforts of its members and with the co-operation of the coal owners, the present well-known home of the Institute, Neville Hall, Newcastle upon T.yne, was built and opened in 1872 .

The beautiful Wood Memorial Hall Library and ideally arranged lecture theatre, together with the other offices provided, bear witness to the professional spirit aroused by the inauguration of the Institute, and have done much to inspire succeeding generations of mining and mechanical engineers in devotion to the task of following the objectives so clearly set out by Nicholas Wood.

In order adequately to maintain this building and to ensure continuity in research, a Centenary Appeal Fund has been opened, and it is hoped that the appeal will meet with generous response.

\section{INTERNATIONAL SEAWEED SYMPOSIUM}

$A$

$\mathrm{N}$ international seaweed symposium, organized by the Institute of Seaweed Research, the University of Edinburgh and the Scottish Marine Biological Association, with the assistance of corresponding delegates from Australia, Canada, Chile, France, Germany, New Zealand, Norway, South Africa, Spain, Sweden and the United States of America, was held in Edinburgh during July 13-17. The symposium, which was the first of its kind, 
attracted world-wide interest, and was attended by some 160 scientists and technologists from more than twenty countries and Colonial dependencies. Lord Bilsland, chairman of the Board of Management of the Institute of Seaweed Research, presided at the opening ceremony in the Zoology Department of the University of Edinburgh and offered a warm welcome to all the members. In his address in formally opening the symposium, Mr. James Stuart, Secretary of State for Scotland, considered that many of our present industrial and agricultural problems might be alleviated to a very appreciable extent by making better use of the hundreds of thousands of tons of seaweed growing naturally around our shores, whether by way of animal feeding-stuffs or in the many other ways which are being investigated by men of science in their present research programmes.

At the first session, which was devoted to "Phycology", Dr. E. M. Burrow's (Great Britain) opened the proceedings with a paper on "Intertidal Plant Populations with Special References to the Genus Fucus", in which she referred to the effect of habitat variation, genetical variation and hybridization occurring in Fucus spiralis, $F$. vesiculosus and $F$. serratus. Dr. D. de Virville (University of Paris) delivered a paper on "Algal Population Decrease on the East Coast of Cotentin", in which he discussed the main types of marine plants gathered for agricultural and industrial use from the Atlantic coast of France. The Fucaceæ (Fucus vesiculosus, F. serratus and Ascophyllum nodosum) are collected chiefly for manure, the Laminariaceæ (Laminaria, Saccorhiza and Alaria species) for the extraction of iodine, Chondrus crispus and Gigartina mamillosa for the preparation of gels, and Zostera marina as a packing or filling material. A progressive decrease of these plant growths, due often to excessive gathering, has been recorded in recent years, and Dr. de Virville suggested that more severe control of harvesting should be introduced in an effort to halt this serious depopulation.

Several papers were devoted to a detailed study of the seaweeds occurring in different parts of the world. Dr. E. Jaasund (Sweden) discussed the marine algæ of the north Norwegian coast-line, Dr. L. Bellon (Spain) dealt with the seaweeds of the Malagan coast, Mr. C. Primo (Spain) described the algal population of Spanish West Africa, and Dr. J. R. Nunn read a paper on the seaweed vegetation of South Africa. Contributions dealing with the purely botanical aspect of the marine algæ were given by Dr. P. Kornmann (Germany), who discussed the development of Giffordia fuscata (Zan), Prof. J. Feldmann (France) on the evolution of the female organs of the Florideæ, Dr. H. B. S. Womersley (Australia) on the Macrocystis species of southern Australia, Dr. ' $T$. Levring on the reduced forms occurring in the Swedish marine flora, and Prof. M. Chadefaud (France) on the staining techniques developed for the cytological study of the algæ. Dr. B. L. Moss (Great Britain) discussed the variation in chemical constitution occurring during the development of the Fucales, and emphasized the importance of giving accurate descriptions of any plant material submitted for chemical analysis. Mr. B. Grenager spoke on the surveying of the Norwegian seaweeds by means of the spring grab technique developed by the Scottish Seaweed Research Association.

"Algal Chemistry" was the subject for the second session, and Prof. T. Dillon (University of Galway) opened the proceedings with a lecture on "The Constitution of Some Seaweed Mucilages". He described the preparation and purification of a polysaccharide sulphuric ester from fruiting Ascophyllum nodosum, which contained one galactose to seven fucose residues and having one sulphate group attached to each monosaccharide anhydride unit. The galactan sulphuric esters from Gelidium latifolium, carragheen moss, Furcellaria fastigiata, Dilsea edulis and Dumontia incrassata were also discussed. Dr. F. J. Coll (Eire) dealt with the constitution of floridean starch extracted from Furcellaria fastigiata and Dilsea edulis, and presented evidence to show, from methylation and $\beta$-amylolysis studies, that at least 50 per cent of the molecule consists of $\alpha$-D-glucopyranose units linked through carbon atoms 1 and 4 as in ordinary starch. The quantitative liberation of carbon dioxide from uronic and polyuronic acids, such as alginic acid, when heated at $255^{\circ} \mathrm{C}$. in the absence of any catalyst, was discussed by Dr. A. S. Perlin (Canada). The evidence suggests that the reaction is a true decarboxylation, and it has been employed for the analysis of several polyuronides, such as oxidized cellulose and starch. Dr. R. W. Watson (Canada) read a paper on "The Molecular Weight of Algin as determined by Sedimentation and Diffusion", in which the weight average molecular weight of four samples of sodium alginate ranged from 32,000 to 165,000 , and appeared to be linearly related to the intrinsic viscosity. The variations in chemical composition among individual Laminaria digitata plants, collected at the same time and from the same habitat, were described by $\mathrm{Mr}$. A. Haug (Norway), who found large individual variations in the dry matter and ash content with smaller variations in the alginate content. $\mathrm{He}$ emphasized the importance of these results in recording analytical data for the brown algæ. The alginate, ash, mannitol, laminarin, combined fucose and iodine content of v.urious South African Phæophyceæ was dealt with in a paper read by Dr. J. R. Nunn, while Mr. C. W. Bonniksen (Great Britain) described the various uses of alginates and alginate materials in medicine and surgery. 'The nitrogenous constituents of the marine algæ were reviewed by Dr. E. Gordon Young (Canada) and Dr. G. T. Young (Great Britain). Algal peptides and proteins are difficult to extract, relatively strong alkali being required to extract 50 per cent of the total nitrogen. Dr. G. T. Young described the nitrogen distribution in various common brown seaweeds between volatile base nitrogen (chiefly ammonia), nitrate-nitrogen and residual Kjeldahl-nitrogen, and pointed out that the $\alpha$-amino-nitrogen after hydrolysis was invariably less than the residual Kjeldahl-nitrogen, due probably to decomposition of the amino-acids in presence of carbohydrates. Acid hydrolysates of $L$. saccharina and $A$. nodosum contained the following amino-acids: glycine, alanine, valine, leucine, isoleucine, aspartic acid, glutamic acid, serine, threonine, proline, phenylalanine, lysine and a trace of arginine. Mr. L. E. Ericson (Sweden) spoke on the occurrence of vitamin $\mathrm{B}_{12}$, folic acid, folinic acid and various aminoacids in different brown and red seaweeds from the Baltic and North Seas; the content of vitamin $B_{12}$ in some algre appears to be comparable with that of liver.

At the session with "Utilization" as the subject, Mr. R. W. Moncrieff (Great Britain) reviewed the present uses of alginates in foodstuffs, textiles, toilet goods, paints and engineering; recent developments include a washable flame-proof fabric and table jellies that set in hot weather. The expansion of the seaweed industry has hitherto been limited not by any shortage of seaweed or difficulty of extracting 
alginates, but by the limited number of known uses for seaweed derivatives, and the development of the alginates is at present being actively studied. The utilization in the United States of agar and carragheenin, the two chief gelling agents extracted from the red algæ, was discussed by Mr. E. C. Jertson (United States), and Dr. D. C. West read a paper on "A Survey of Certain Seaweeds of Commercial Importance in South West Nova Scotia". The survey revealed the presence of approximately 200,000 tons of rockweed, 900,000 tons of Laminaria spp., while in 1950 almost 8,000,000 lb. of Chondrus were harvested. Recolonization of these species was also discussed. Industrial applications of the seaweeds in Spain were dealt with by Dr. J. Aravio-Torre, who spoke of the rapidly increasing production of agar from 1944 to the present time, production in 1951 amounting to some $62,000 \mathrm{lb}$.; the brown seaweed industry, however, has not grown to the same extent. The session on utilization was concluded by Mr. C. J. F. Hand (Great Britain), who described the results of feeding various seaweed meals to laying hens; the introduction of 10 per cent of seaweed meal into the basal ration, although causing increased water consumption, did not produce any ill-effect upon egg production, egg weight and shell weight in small-scale trials of 100 days involving groups of four birds. When 15 per cent of the basic ration, however, was replaced, water consumption was further increased, and live-weight and egg production decreased.

The final session, entitled "World Seaweed Resources", was introduced by Dr. F. N. Woodward (director of the Institute of Seaweed Research), and the following spoke on the seaweed resources of their respective countries : Dr. H. B. S. Womersley (Australia and New Zealand), Dr. D. C. West and Dr. G. M. Shrum (Canada), Mr. E. C. T. Holsinger (Ceylon), Prof. H. Etcheverry (Chile), Dr. S. Lund (Denmark), Mr. D. T. Flood (Eire), Prof. J. Feldmann (France), Prof. C. Hoffmann (Germany), Mr. F. T. Walker (Great Britain), Dr. J. R. Nunn (South Africa), Dr. L. Bellon (Spain), Dr. T. Levring (Sweden), and Mr. G. W. Anderson (Zanzibar). Papers from the following authors, who were unable to attend the symposium, were read by title: Prof. T. Rayss (Israel), Dr. S. Suto (Japan), Prof. 'T. Braarud (Norway), Dr. G. T. Velasquez (Philippines), and Drs. K. S. Pillai and N. S. Varier (Travancore-Cochin).

Many members contributed to the discussion on each group of papers at the end of the various sessions, and a résumé of these discussions, together with abstracts of the complete set of papers presented and read by title, will appear in the "Proceedings" of the symposium, copies of which should be available before the end of this year. Dr. M. Knight (Great Britain), Dr. T. Levring (Sweden), Prof. C. G. C. Chesters (Great Britain), Dr. E. Gordon Young (Canada), Prof. E. L. Hirst (Great Britain), Mr. E. C. Jertson (United States) and Dr. F. N. Woodward (Great l3ritain) presided at the various sessions.

'There were three excursions connected with the symposium. On July 13, a joint meeting with the British Phycological Group was held at St. Andrews, where members and their friends visited the Gatty Marine Laboratory and were given ample opportunity of studying the marine flora of that part of the coast. On the afternoon of July 15, members visited the Institute of Seaweed Research, Inveresk, Midlothian, to inspect the laboratories and workshops. Mr. Philip Jackson, deputy director of the Institute, gave a brief description of the different methods developed for harvesting sublittoral brown seaweeds, and on the morning of July 17 demonstrations of this equipment were held at Dunbar and Fisherrow.

There were also three social events held during the evenings. On July 14, delegates were provided with an opportunity of meeting in very pleasant circumstances at a cocktail party given by the Secretary of State for Scotland, while on July 16 the Magistrates and Council of the City of Edinburgh showed their interest in the purpose of the symposium by holding a reception in honour of its members in the City Chambers; in the absence of the Lord Provost, members were welcomed by Senior-Bailie James Campbell, and Mr. E. C. Jertson replied for the visitors. On July 15, a dinner was held in the hall of the Royal College of Surgeons, where the principal speakers were Dr. F. N. Woodward and Sir Alexander Gray, professor of commercial and political economy and mercantile law in the University of Edinburgh.

Dr. T. Levring expressed the feelings of members when, at the closing session, he spoke of the success of the symposium, not only from a scientific but also from a social point of view. He suggested that the next symposium should be held in Norway three years hence, and this motion was very cordially supported.

E. T. Dewar

\section{NEWS and VIEWS}

\section{Commonwealth Scientific and Industrial Research Organization: Mr. G. A. Cook}

Mr. G. A. Cook is retiring from the post of secretary of the Commonwealth of Australia Scientific and Industrial Research Organization, after thirty years with the Organization and its predecessors, the Institute of Science and Industry and the Council for Scientific and Industrial Research. Mr. Cook graduated at the University of Melbourne with first-class final honours in science and in mining engineering. After service in the First World War, he worked with Sir Edgeworth David collating geological information from the French and Belgian Geological Surveys, and on his return to Australia undertook research in several phases of the mining and metals industries. When Mr. Cook joined the Institute of Science and Industry as scientific abstractor in 1922, there were only two people with a scientific training on the staff. He has seen the growth of that Institute into the present Organization, with a total staff of more than three thousand, including eleven hundred scientists. In 1927 he was appointed assistant secretary to the Council for Scientific and Industrial Research, and for many years was also officer in charge of its Information Service. He succeeded Mr. G. Lightfoot as secretary in 1944. Mr. Cook has always kept in personal touch with all phases of the Organization's work, and his long service as an administrator has given him wide experience of science and its organization. He has taken a particular interest in making the results of scientific research available to industry both as an editor of scientific publications and as a writer of non-technical accounts for the general reader.

The administrative work of the Commonwealth Scientific and Industrial Research Organization will now be the responsibility of four senior members of the secretariat: Mr. F. G. Nicholls, secretary (general administration); Mr. G. B. Gresford, 